Zwracając uwage na brak w piśmiennictwie pedagogicznym systematycznie prowadzonej informacji bibliograficznej, Stefan Wołoszyn zamieszcza w swojej książce omówienie niektórych bibliografii, czasopism, encyklopedii i ważniejszych serii wydawniczych.

Cennym źródlem informacji, zwłaszcza dla studentów poszukujących aktualnych i najważniejszych opracowań w danej dziedzinie, będzie wybór bibliografii zaproponowany przez autora. $\mathrm{Na}$ końcu znajdziemy także indeks osób wymienionych $\mathrm{w}$ tekście $\mathrm{z}$ wyszczególnieniem stron. Jako ciekawostkę podam, iż Bogdana Suchodolskiego wymieniono tu 45 razy, potem Zygmunta Mysłakowskiego - 21 razy, Wincentego Okonia - 20 razy i tyle samo Bogdana Nawroczyńskiego. Spośród naukowców zwiq̨zanych ze środowiskiem UAM najczęściej przywoływano Zbigniewa Kwiecińskiego - 19 razy,
Lecha Witkowskiego - 13 razy i Marię Dudzikowa -8 razy.

Indeks wybranych zagadnień i terminów jest nowością w drugim wydaniu i może znakomicie ułatwić poszukiwania tematyczne.

Do książki dołączono spis treści III tomu „Źródel do dziejów wychowania i myśli pedagogicznej" (w XX stuleciu), który to tom jest skorelowany $z$ omawianą książka-

Wydaje się, że praca, której drugie wydanie prezentuje Stefan Woloszyn nie tylko ulatwia studiowanie pedagogiki i kształcenie nowych pokoleń pedagogów, ale zawiera w wielkiej kondensacji ogromny zasób informacji o wychowaniu, kształceniu, o myśli pedagogicznej, o pedagogach i ich książkach.

Urszula Moskalik

\title{
Franciszek Ziemski, Wybrane problemy tradycji i wychowania w polskich dziejach (X w. - XVIII w.), Prace Naukowe Uniwer- sytetu Śląskiego w Katowicach nr 1787, Katowice 1999, Wydawnic- two Uniwersytetu Sląskiego, sS. 122
}

Praca Franciszka Ziemskiego jest pierwsza cześcią całościowego opracowania dziejów wychowania w Polsce i kształtowania się tradycji narodowej. Następne tomy poświęcone będa XIX i XX stuleciom. Opracowanie składa się ze wstępu, pięciu rozdziałów, zakończenia oraz aparatu naukowego - stosunkowo obszernej bibliografii, indeksu osobowego i streszczeń w jezzykach angielskim $\mathrm{i}$ niemieckim.

We wstępie Autor pisze, że korzystał z dorobku nauk historycznych oraz filozofii, pedagogiki, socjologii i antropologii kultury, co trzeba przyznać, zachęca do wnikliwej lektury.

Rozdział I pt. „Niektóre problemy teoretyczne i metodologiczne", poświęcony zostal omówieniu znaczenia i rozumienia terminu tradycja. Odwołując się do warsztatu naukowego historii, socjologii, nauk politycznych, pedagogiki i filozolii, przedstawia to zagadnienie w szerokim spektrum. Autor porusza tu także kwestię transmisji tradycji, dzięki której dziedzictwo narodowe jest przypominane i ożywiane. F. Ziemski podkreśla fakt, iż tradycja jest wielką siłą edukacyjną. Dzięki kumulującemu się doświadczeniu kolejnych pokoleń człowiek mógl stworzyć cywilizację. Autor snuje też rozważania nad zakresem pojęciowym tradycji, kultury, więzi spolecznej.

Rozdział II zatytułowany jest „Wchodzenie Polski w tradycje i modele europejskiego wychowania". Katowicki badacz pisze tu o oddziaływaniu kultury starożytnej Grecji i Rzymu na ziemie państwa przodków Mieszka I. Omawia dzieje plemion zamieszkujące ziemie położone między Odrą i Bugiem, cywilizacyjny wpływ przyjęcia chrześcijaństwa, kontakty Polski z Cesarstwem Rzymskim Narodu Niemieckiego ${ }^{1}$. Poświęca też uwagę kształtowaniu się 
organizacji kościelnej i szkolnictwa na ziemiach polskich.

W rozdziale III pt. „Problemy tradycji i wychowania w Polsce doby Renesansu" F. Ziemski podkreśla ogromne znaczenie powstania w 1364 r. uniwersytetu w Krakowie dla rozwoju kultury narodowej. W czasach Kazimierza Wielkiego powstało nowe, stanowe społeczeństwo. Zaczęła się kształtować tradycja, oparta na słowie pisanym. Po zreformowaniu (26 lipca 1400) Uniwersytet stał się szybko ogniskiem kultury wysokiej, przyciągającym licznych studentów $\mathbf{z}$ wielu krajów europejskich. Jak podaje F. Ziemski, w pierwszym roku zapisało się do metryki uniwersyteckiej 205 studentów, a w stosunkowo krótkim czasie uczelnia miała ok. 6 tysięcy scholarów. Uniwersytet zaczął przyciągać wybitnych drukarzy, stał się centrum kształtowania polskiej myśli politycznej.

Autor omówił następnie cywilizacyjna rolę Kościoła, który propagował w średniowieczu uniwersalistyczny model kultury sprzyjający przyspieszeniu rozwoju cywilizacyjnego nowych państw, które weszły w orbitę oddziaływania kultury łacińskiej. $Z$ czasem jednak zaczął obawiać się wykształcenia niezależnej kultury narodowej, co krytykował szczególnie Andrzej Frycz Modrzewski.

Dalszą część rozdziału wypehniają rozważania F. Ziemskiego dotyczące reformacji, kontrreformacji, modelu tradycji odrodzeniowej. Badacz omówil tu także skomplikowane procesy zachodzące $w$ spoleczeństwie polskim w XV i XVI w. Jego uwagę skupił szczególnie proces zamykania się stanu szlacheckiego, który zaczął zajmować coraz bardziej dominująca pozycję w społeczeństwie, gwarantując sobie monopol na sprawowanie władzy (konstytucja Nihil Novi z 1505 r.). Końcowa część rozdziału traktuje o kulturze szlacheckiej, o wyjazdach naukowych, przy czym Autor korzysta $z$ literatury nie uwzględniającej najnowszego stanu badañ $^{2} \mathrm{i}$ nie jest to bynajmniej przypadek odosobniony, o czym szerzej w końcowej części tej recenzji.

Rozdział IV („Sarmacka ideologia i wychowanie") traktuje o historiograficznym micie, który narodził się w Polsce w XVI-XVII w. Poglad ten stanowi, że Polacy (szlachta) wywo- dzą się od Sarmatów, koczowniczego ludu pochodzenia irańskiego. $Z$ tej koncepcji genealogicznej polskiej szlachty wywodzi się swoisty typ polskiego konserwatyzmu. W XVII w., gdy dokonała się ostatecznie polonizacja stanu szlacheckiego, język i katolicyzm stały się wyróżnikiem szlacheckości. Nastąpiło także stopniowe zamykanie się horyzontów intelektualnych elity polskiego społeczeństwa w obronie zzekomych ideałów złotej wolności szlacheckiej. Zdaniem Autora zaściankowość i prymitywny tradycjonalizm to glówne cechy umysłowości szlacheckiej w XVII i pierwszej połowie XVIII w.

W tym samym jednak czasie zaczęła się walka o reformy społeczne. Pierwsze zmiany nastapity w czasach Augusta III, lecz dopiero panowanie Stanisława Augusta Poniatowskiego przyniosło konkretne działania reformatorskie. F. Ziemski omówił reformy polskiego oświecenia, które natrafiały na opór dogmatycznie i tradycjonalistycznie myślącej części szlachty. Zauważa przy tym, że powoli zaczęły formować się dwa modele myślenia o przeszłości narodowej: legendarny, apologiczny i tradycjonalizm ideologiczny.

Ostatni, piąty rozdzial omawianego opracowania, zatytułowany: „Walka o tradycje i nowy model wychowania w dobie oświecenia" poświęcony został prezentacji działalności reformatorskiej Stanisława Konarskiego, Stanisława Augusta Poniatowskiego i innych wybitnych polityków, naukowców, pisarzy i artystów. Nie zabrakło $w$ tym przeglądzie również reformatorsko nastawionych przedstawicieli obozu niechętnego zmianom proponowanym przez Obóz Reform - szczególnie Michała Wielhorskiego.

Autor zauważa, iż reformatorzy oświeceniowi stworzyli własną wykładnie tradycji narodowej, która miała stać się podporą dokonujących się przemian. Podkreślali oni znaczenie silnej władzy królewskiej, dążąc do przywrócenia zasady dziedziczności tronu. Istotna byla dla nich także zasada równowagi między stanami. F. Ziemski przedstawił tu również dokonania Szkoły Rycerskiej i Komisji Edukacji Narodowej. Podkreślił, że polskie Oświecenie miało swoje specyficzne cechy, odmienne od zachodnioeuropejskiego ruchu oświeceniowego. 
W zakończeniu Autor zauważa, że w wiekach X-XIII tradycja ustna nie sprzyjała rozwojowi państwa. Dopiero tradycja oparta na przekazie pisanym przestała być jednowymiarowa. Od momentu powstania Akademii w Krakowie rozpoczął się nowy okres w rozwoju państwa i narodu polskiego. W XVI w. tradycja narodowa miała charakter otwarty, natomiast w XVII w. zwyciężyły tendencje zachowawcze, niesprzyjające rozwojowi kraju.

Pozycja została zaopatrzona w bibliografię, która - co trzeba zaznaczyć - jest znacznie bogatsza od listy prac uwierzytelnionych w przypisach.

Książka Franciszka Ziemskiego przedstawia szerokie spektrum zagadnień zwiq̨zanych z dziejami kształtowania się tradycji narodowej, co niewątpliwie podwyższa jej wartość. Na podkreślenie zasługuje również fakt, iż jest ona próbą syntetycznego ujęcia problemu. Niestety praca nie jest wolna od błędów - w tym również merytorycznych! Swq listę zarzutów rozpocznę od analizy podstaw materiałowych niniejszego opracowania. Przede wszystkim zastanawiajace jest całkowite niemal pomijanie materiałów źródłowych. Jeżeli nawet odnajdujemy $w$ tekście odniesienia do źródel, to sq one zawsze niemal „z drugiej ręki". Wbrew zapowiedziom Autora trudno odnaleźć również ślady dorobku takich dziedzin nauki jak antropologia kulturowa, socjologia czy filozofia. Kolejnym, jak się wydaje, poważnym mankamentem, jest notoryczne pomijanie w treści książki najnowszych opracowań. Praca wydana została w 1999 roku, a próżno jest szukać w przypisach tytułów dzieł powstałych choćby w początku lat dziewiéćdziesiątych. Autor powoluje się na wiedzę ogólnz̧ podręcznikową i nie wykorzystuje literatury fachowej. Tytulem przykładu, omawia wpływ kultury greckiej i rzymskiej na kształtowanie się monarchii piastowskiej, powołując się na podrẹczniki historii wychowania Stanisława Kota czy Antoniego Karbowiaka, które - w niczym nie uchybiając ich wartości poznawczej - przedstawiają stan wiedzy na koniec XIX w. ${ }^{3}$ Podobnie jest $\mathrm{z}$ syntezami dziejów Polski: wybitne w swoim czasie prace Joachima Lelewela, Michała Bobrzyńskiego są już mocno zdezaktualizowane.
F. Ziemski powołuje się na prace wielu autorów w sposób pośredni, nie sięgając do nich.

W pracy pojawiają się mniej lub bardziej rażące błędy merytoryczne. Szczególnie „skażony" jest nimi rozdział II. I tak Autor pisze: „Słowianie (także polscy) wypełnili przestrzeń po ludach germańskich (gockich), które w IV wieku uciekały w poplochu przed Hunami" - gdy tymczasem przyłączyły się one do substratu huńskiego. Poza tym Goci byli ludem germañskim, jest to więc pojęcie węższe ${ }^{4}$. Dalej czytamy: „wtedy zaczyna się historia Slowian w Europie [...] ludu, który opanowal i zasiedlił część kontynentu europejskiego, spychając m.in. Niemców za Labę" ". Tymczasem o Niemcach jako o grupie etnicznej można mówić dopiero od czasów traktatu w Verdun (843), natomiast ekspansja niemiecka na tereny nad Labą sięga dopiero X-XI w. i to w bardzo ograniczonym wymiarze ${ }^{6}$. Nie można zgodzić się również $z$ teza Autora, że na ziemiach polskich najwcześniej rozwinął się ośrodek państwowości na południu, bowiem $w$ tym samym czasie formowal sie ośrodek Polan nad Gopłem i środkową Wartą ${ }^{7}$. Na stronie 48 odnaleźć możemy sygnalizowany już anachronizm w nazwie Cesarstwa, nieco wcześniej (przypis 13 ze strony 46) Autor twierdzi, że systematyczne ksztalcenie kleru zapoczątkował biskup Metzu św. Chrodegang (712 - 766). Tymczasem zasady prawne, regulujące funkcjonowanie szkoły biskupiej (katedralnej) sformułowane zostaly na synodzie w Toledo w 527 roku $^{8}$.

We wstępie Autor twierdzi, że „chlopstwo zostało pozbawione dostępu do szkól. Pańszczyzna i przypisanie do ziemi odsunęły chlopów od uczestnictwa w życiu społeczno-politycznym aż po XX wiek" nie zauważając dość licznych chłopów - absolwentów krakowskiej Alma Mater, tudzież aktywności chłopskiej w okresie powstań narodowych i Wiosny Ludów - to przecież schyłek XVIII i XIX w.

Nie można zgodzić się również ze zdaniem Autora (przypis 13, s. 71) w kwestii zmian w stukturze gospodarczej - swoistej specjalizacji w strukturze produkcji w Europie wschodniej i zachodniej, a także, iż problemy zmian w społeczeństwie w XV i XVI w. „w literaturze, nie tylko historycznej, nie zostały w pelni omówione". Istnieją przecież znakomite opracowania Jerzego Topolskiego ${ }^{9}$. 
Reasumując niniejsze rozważania, książka Franciszka Ziemskiego mimo niewątpliwych zalet, pozostawia w Czytelniku wrażenie sporego niedosytu. Miejmy nadzieje, że kolejne tomy wydawnictwa będą znacznie lepsze, a Autor wystrzeże się sygnalizowanych błędów.

Krzysztof Ratajczak

1 Autor używa przy tym terminu Cesarstwo Niemieckie, odnoszącego się do państwa niemieckiego powstakego po zwycieskiej wojnie z Francja w 1870 r.

2 Zawarte są one choćby w pracy Doroty Zolądź-Strzelczyk, Peregrinatio academica. Studia mlodzieży polskiej z Korony $i$ Litwy na akademiach $i$ uniwersytetach niemieckich $w \mathbf{X V} i$ pierwszej polowie X VI wieku, Poznań 1996; por. taż, Idealy edukacyjne doby staropolskiej, Warszawa 1990.

${ }^{3}$ Podstawową literature przedmiotu podaje ostatnio Leszek Mrozewicz, Historia powszechna. Starożytnośs, Poznań 1999.

4 Por. J. Strzelczyk, Goci-rzeczywistosć $i$ legenda, Warszawa 1984; tenże, Wandalowie $i$ ich afrykańskie państwo, Warszawa 1992.

5 F. Ziemski, Wybrane problemy tradycji $i$ wychowania w polskich dziejach ( $X$ w. $-X V I I$ w.), Katowice 1999, s. 38.
6 Zob. J. Strzelczyk, Po tamtej stronie Odry. Dzieje $i$ upadek Slowian polabskich, Poznań 1968; tenże, Slowianie i Germanie w Niemczech srodkowych we wczesnym śdedniowieczu, Warszawa 1976, tenż, Od Praslowian do Polaków, Poznań 1987. Por. też liczne prace Gerarda Labudy zebrane w tegoż, Polsko-niemieckie rozmowy o przeszlości, Zbiór rozprow i artykulów, Poznań 1996; tu dalsza literatura przedmiotu.

7 Zob. J. Wyrozumski, Welka historia Polski, t. 2, Dzieje Polski piastowskiej ( VII wiek - 1370), Kraków 1999, s. 66-70. Por. także liczne prace Henryka Lowmiańskiego na czele $\mathrm{z}$ monumentalnymi Poczqtkami Polski, t. 1-6, Gerarda Labudy i in.

B J. Ehlers, Domschulen, w: Lexicon des Mittlealters, t. III, München-Zürich 1986, kol. 1226; por. K. Stopka, Szkoly katedralne metropolii gnieźnieniskiej $w$ średniowieczu. Studia nad ksztalceniem kleru polskiego w wiekach średnich, Kraków 1994, s. 10 .

9 J. Topolski, O literaturze $i$ praktyce rolniczej w Polsce na przelomie XVI Dziejow Spolecznych i Gospodarczych" 14 (1952/1953), s. 43-106; tenże, Narodziny kapitalizmu w Europie $X I V-X V I$ wieku, Warszawa 1965; tenże, Gospodarka polska a europejska w XVI-XVI wieku, Poznań 1977; tenże, Polska w czasach nowożytnych. Od środkowoeuropejskiej potegi do utraty niepodleglości (1501-1795), Poznań 1994, tu dalsza literatura.

\section{Noty}

\section{Humanistyka przelomu wieków, pod red. Józefa Kozieleckiego, Wydawnictwo Akademickie "Żak", Warszawa 1999, ss. 417}

Schyłek wieku zawsze przynosi ze sobą fale podsumowań, rozliczeń, ocen upływającego czasu. Człowiek ma tendencje do spoglądania w przeszłość przy okazji mijania kolejnych słupów milowych wyznaczających lata, dekady, wieki. Retrospekcja jest tym bardziej zrozumiała, gdy zbliża się ku końcowi milenium. W nurt prac, dla powstania których mijające tysiąclecie stanowiło impuls, wpisuje się niewątpliwie $\mathrm{Hu}$ manistyka przelomu wieków pod redakcją Józefa Kozieleckiego.

Redaktor tomu podzielił zawarte w nim teksty na cztery części. „Część pierwsza - problemowa - poświęcona jest globalnym i lokal- nym dylematom czlowieka, takim jak edukacja, demografia, zdrowie czy religia" (s. 9). Otwiera ją tekst Jerzego Z. Holzera Trzy procesy demograficzne. Tytułowe, najistotniejsze procesy demograficzne, o których pisze Autor to: zwiększanie się liczby ludności świata, zjawisko starzenia się ludności i postępująca urbanizacja.

Wiara $w$ godzinie przelomu ks. Józefa Tischnera to między innymi rozważania na temat zagrożeń wewnętrznych i zewnętrznych, które moga doprowadzić do przecięcia więzi łączących wiernych z Kościołem. Wśród zagrożeń zewnętrznych ks. Tischner odnotowuje „wyzysk religii do celów politycznych". Jest to dla Koś- 